\title{
Anaplastic Thyroid Cancer: A Review of Epidemiology, Pathogenesis, and Treatment
}

\author{
Govardhanan Nagaiah, ${ }^{1}$ Akm Hossain, ${ }^{2}$ Colin J. Mooney, ${ }^{3}$ James Parmentier, ${ }^{4}$ \\ and Scot C. Remick ${ }^{1}$
}

${ }^{1}$ Mary Babb Randolph Cancer Center, West Virginia University, Morgantown, WV 26508, USA
${ }^{2}$ Ellis Fischel Cancer Center, University of Missouri, Columbia, MO 65203, USA
${ }^{3}$ Department of Medicine, University of Michigan, Ann Arbor, MI 48109, USA
${ }^{4}$ Graduate Program in Clinical Investigation, MGH Institute of Health Professions, 36 1st Avenue,
Charlestown Navy Yard, Boston, MA 02129, USA

Correspondence should be addressed to Scot C. Remick, sremick@hsc.wvu.edu

Received 25 February 2011; Accepted 3 April 2011

Academic Editor: V. Valentini

Copyright (C) 2011 Govardhanan Nagaiah et al. This is an open access article distributed under the Creative Commons Attribution License, which permits unrestricted use, distribution, and reproduction in any medium, provided the original work is properly cited.

\begin{abstract}
Anaplastic thyroid cancer (ATC) is an uncommon malignancy of the thyroid. Only 1-2\% of thyroid cancers are anaplastic, but the disease contributes to $14-50 \%$ of the mortality with a median survival of 3 to 5 months. Most patients diagnosed with this disease are 65 years of age or older. The incidence of anaplastic thyroid cancer is decreasing worldwide. Most patients present with a rapidly growing neck mass, dysphagia, or voice change. We performed a comprehensive literature search using PubMed focusing on the treatment of anaplastic thyroid cancer including historical review of treatment and outcomes and investigations of new agents and approaches. A total of sixteen chart review and retrospective studies and eleven prospective studies and/or clinical trials were reviewed. The current standard therapeutic approach is to consider the disease as systemic at time of diagnosis and pursue combined modality therapy incorporating cytoreductive surgical resection where feasible and/or chemoradiation either concurrently or sequentially. Doxorubicin is the most commonly used agent, with a response rate of $22 \%$. Several new agents are currently under investigation. Referral of patients for participation in clinical trials is needed.
\end{abstract}

\section{Introduction}

Anaplastic thyroid cancer (ATC) is one of the most aggressive solid tumors to affect humans, with a median survival on the order of 3 to 5 months following diagnosis [1-25]. Oneyear and 10-year survival rates are estimated at 10-20\% and less than 5\%, respectively, though some reports question the reliability of diagnoses in these long-term survivors $[11,26,27]$. Even though less than $1-3 \%$ of all thyroid cancers are anaplastic tumors, it contributes up to $14-50 \%$ of the annual mortality associated with thyroid cancer $[8$, $11,28]$. Recent advances in understanding the genetic and molecular pathogenesis of ATC hold promise for targeted therapy for this disease. ATC is usually resistant to standard chemotherapy. There are several clinical trials underway with small molecule tyrosine kinase inhibitors, antiangiogenesis agents and vascular-disrupting agents which might offer more drugs in the therapeutic armamentarium to combat this disease.

\section{Clinical Experiences at Our Institution}

We identified all the cases of ATC from 1987 to 2007 at the Mary Babb Randolph Cancer Center, Morgantown, WVa, USA. Appropriate IRB approval was obtained. Data was collected on demographics, grade, stage, and different modalities of treatment and survival. SPSS was used to analyze the demographic and survival data.

A total of 11 cases were identified at our cancer center from 1987 to 2007. Out of these patients, 7 (64\%) were female and $4(36 \%)$ were male $(P<.001)$. The average 
age of diagnosis was 69 years. The average age was 70 years among female and 67 years among male patients. All of these patients were white and had grade IV disease (100\%) at diagnosis. Eight $(73 \%)$ patients had stage IV diseases at the time of diagnosis, and only three patients (one from each stage) had stage I to III diseases at the time of diagnosis. Most patients received combination therapy that consisted of surgery and radiation. Eight (73\%) had surgery, eight $(73 \%)$ patients received radiation therapy, and only $5(45 \%)$ patients received chemotherapy. Patients with stage IV diseases at diagnosis, who received surgery followed by radiation therapy, had significantly longer survival than the patients with stage 4 diseases at diagnosis who received surgery after chemotherapy or radiation therapy (44 months versus 9 months, $P<.0001)$. The patients who received surgery had significantly better survival than the patients who did not receive surgery $(P<.001)$. In our cohort of 11 patients, multimodality treatment consisting of surgery in combination with either radiation or chemotherapy had better outcomes than any of these treatments alone.

\section{Incidence}

ATC is primarily a disease of the elderly. In one American and German prospective study of 5,583 cases of thyroid carcinoma, $67 \%$ of patients who had ATC were over 70 years of age. In the same study, females constituted $70 \%$ and males $30 \%$ of ATC patients [7].

Based on epidemiological studies derived from the Surveillance, Epidemiology and End Results (SEER) database, the incidence of ATC has held steady in the United States during the period between 1973 and 2002 [29]. The incidence of ATC is estimated at 1 to 2 cases per million population per year, and the trend has been decreasing even though the incidence of well-differentiated subtypes (e.g., papillary and follicular) of thyroid cancer has been increasing [29]. In a retrospective cohort analysis done by Davies and colleagues using the SEER database, there were roughly 24,000 new cases of thyroid cancer in 2002 of which ATC constituted 2\% [29]. A study done in Rochester, Minnesota found that the age-adjusted incidence of ATC was 0.1 per 100,000 person/year (95\% Confidence Interval (CI) $0.0-0.3$ ) [2]. From 1973 to 2002, there was a 2.4-fold increase in all thyroid cancer with no significant change in the incidence of ATC. Papillary thyroid cancer, which increased from 2.7 to 7.7 per 100,000 , contributed to almost all of the increase. It should be noted that cancers less than one centimeter accounted for $49 \%$ and tumors less than two centimeter accounted for $87 \%$ of the increase in the period between 1988 and 2002. There was no change in the mortality associated with thyroid cancer during the same period. This raises the question whether early diagnosis was leading to unnecessary interventions.

Studies published from Italy showed a reduction of ATC from $4 \%$ to $1 \%$ between 1969 and 1973, while another study in India showed a decline from $8 \%$ to $4 \%$ between 1989 and 1993 [42-44]. Although well-differentiated thyroid cancer has increased in Japan, the incidence of ATC has remained stable $[45,46]$. In Sri Lanka, a study that looked at the incidence of thyroid cancer over 28 years, reported a significant reduction of anaplastic histology [47]. The incidence of ATC did not change significantly in a study from Scotland [48]. One for the decreasing incidence of ATC in these several locations could be that a more accurate diagnosis is being made.

\section{Risk Factors}

In one study, $25 \%$ of the ATC patients had a prior history of thyroid goiter and another $10 \%$ with family history of goiter [7]. Other studies have reported a similar association between goiter and ATC [49]. It is also known that ATC is more common in places with endemic goiter, and thus with improvements in iodine supplementation, the incidence of this tumor would be expected to decline. Besic and colleagues report in a study from Slovenia that when the iodination of salt was increased from $10 \mathrm{mg}$ of potassium iodide $/ \mathrm{kg}$ since 1972 to $25 \mathrm{mg}$ of potassium iodide/kg between 1997 and 1998 to 2008, the mean incidence of ATC decreased from 6.2 (range, 3-12) between 1972 and 1997 to 4 (range, 2-10) between 1998 and 2008 [50].

\section{Presentation}

Local symptoms of ATC most commonly begin with a rapidly evolving central neck mass (77\%) followed by noticeable dysphagia (40\%), voice change or hoarseness $(40 \%)$, and stridor (24\%). Regional symptoms included a noticeable lymph node mass (54\%) and neck pain (26\%). Systemic symptoms include anorexia, weight loss, and shortness of breath with pulmonary metastases. Metastases were found in $50 \%$ of patients at presentation with $25 \%$ developing metastasis during the course of disease. Lungs ( $80 \%)$, bone $(6-16 \%)$, and brain $(5-13 \%)$ were the most common sites of metastasis [8].

\section{Prognosis}

In an analysis of survival of ATC patients from the SEER database from 1983 to 2002, which included patients who survived for more than a month, the median survival was 4 months. On multivariate analysis, distant or metastatic disease, tumor size greater than 7 centimeters, and treatment with surgery with or without radiotherapy were statistically significant prognostic markers $(P \leq .05)$. Of interest, when the authors stratified patients by the extent of disease and looked into the benefit of radiotherapy after surgery, they found that patients with extracapsular extension into adjacent tissue, the addition of radiotherapy was of benefit. Radiotherapy after surgery was of no benefit in patients who had disease confined to the thyroid or had distant metastasis [51]. Age, sex, size of the tumor, resectability, and the extent of disease has been shown to affect the course of the disease [27]. In a SEER-based study in the United States by multivariate analysis, only age less than 60 years, an intrathyroidal tumor, and the combined use of surgical and external beam radiation therapy were identified 
TABLE 1: Chart review and retrospective studies.

\begin{tabular}{|c|c|c|c|c|c|}
\hline Authors & Year & Site & $\begin{array}{c}\text { No. of } \\
\text { pts }\end{array}$ & Study details & Results \\
\hline $\begin{array}{l}\text { Swaak-Kragten } \\
\text { et al. [30] }\end{array}$ & 2009 & Netherlands & 75 & $\begin{array}{c}\text { Chart Review } \\
\text { 1972-2003 }\end{array}$ & $\begin{array}{l}\text { When treated with Doxorubicin and radiation, the median } \\
\text { survival was } 3 \text { months. } 1 \text { yr OS was 9\%. Locoregional control } \\
\text { was significantly higher in patients who had undergone } \\
\text { R0/R1 resection or chemoradiation, with best results for } \\
\text { patients who underwent both (complete remission in } 89 \% \text { ). }\end{array}$ \\
\hline Vrbic et al. [31] & 2009 & Serbia & 16 & $\begin{array}{c}\text { Chart Review } \\
\text { 1997-2007 }\end{array}$ & $\begin{array}{l}\text { Radiation was combined with doxorubicin } 60 \mathrm{mg} / \mathrm{m}^{2} \text { and } \\
\text { cisplatin } 40 \mathrm{mg} / \mathrm{m}^{2} \text { every } 3 \text { weeks. Overall response rate was } \\
\text { of } 25 \% \text { ( } 95 \% \text { CI: } 7-55) \text {. Mean patient OS was } 12.33 \text { months } \\
(95 \% \text { CI: 9.09-15.56) and median OS } 11.0 \text { months ( } 95 \% \text { CI: } \\
8.56-13.44) \text {. }\end{array}$ \\
\hline Yau et al. [32] & 2008 & Hong Kong & 50 & $\begin{array}{c}\text { Chart review } \\
\text { 1996-2006 }\end{array}$ & $\begin{array}{l}\text { Median survival was } 97 \text { days. On univariate analysis, age } \leq \\
65(P \leq .01) \text {, absence of metastatic disease at presentation } \\
(P<.01) \text {, surgical resection }(P<.01) \text {, and postoperative } \\
\text { radiotherapy was associated with longer survival. Cytotoxic } \\
\text { chemotherapy was not associated with longer survival. }\end{array}$ \\
\hline Lim et al. [33] & 2007 & USA & 37 & $\begin{array}{c}\text { Chart review } \\
\text { 1984-2006 }\end{array}$ & $\begin{array}{l}\text { A median radiation of dose } 5760 \mathrm{cGy},>4500 \mathrm{cGy} \text { in } 32 \text { ( } 87 \%) \\
\text { was administered through hyperfractionated or once-daily } \\
\text { schedules. Median number of treatments received } 6,>4 \text { in } 24 \\
(65 \%) .2 \text {-year outcomes: locoregional control } 25 \% \text {; } \\
\text { progression free survival } 8 \% \text {; overall survival } 18 \% .6 \text { patients } \\
\text { remained alive at the time of last followup with survival } \\
\text { durations of } 4,11,12,57,59 \text {, and } 141 \text { months, respectively. }\end{array}$ \\
\hline Lee et al. [34] & 2006 & Korea & 15 & $\begin{array}{c}\text { Chart review } \\
\text { 1988-2003 }\end{array}$ & $\begin{array}{l}\text { The mean overall survival time of the } 15 \text { patients was } 237 \\
\text { days (range, } 28-717 \text { days). The } 6,12,18 \text {, and } 24 \text {-month } \\
\text { survival rates were } 33 \%, 26 \%, 13 \% \text {, and } 0 \% \text {. }\end{array}$ \\
\hline Wang et al. [35] & 2006 & Canada & 47 & $\begin{array}{c}\text { Chart review } \\
\text { 1983-2004 }\end{array}$ & $\begin{array}{l}\text { The 6-month local progression-free success rate was } 95 \% \\
(P=.0001) \text { with radical radiotherapy }>40 \text { Gy compared to } \\
64 \% \text { with palliative radiotherapy at }<40 \text { Gy. Survival was } 11 \\
\text { months with radical and } 3 \text { months with palliative } \\
(P=.0001) \text {. The median overall survival time in patients } \\
\text { with twice-daily fractionation ( } 13 \text { months) was } 3 \text { months } \\
\text { longer than patients treated with once-daily fractionation } \\
\text { (10 months), but the difference was not statistically } \\
\text { significant }(P=.3) \text {. }\end{array}$ \\
\hline Veness et al. [36] & 2004 & Australia & 18 & $\begin{array}{c}\text { Chart review } \\
\text { 1979-2002 } \\
\end{array}$ & Median survival was 6.2 months. \\
\hline Haigh et al. [6] & 2001 & Canada & 33 & Chart review & $\begin{array}{l}\text { In patients treated with potentially curative resection, } \\
\text { median survival was } 43 \text { months and was } 3 \text { months with } \\
\text { palliative resection }(P=.002) \text {. The median survival of } 3.3 \\
\text { months with only chemotherapy and irradiation and } \\
\text { palliative resection }(P=.63) \text {. }\end{array}$ \\
\hline McIver et al. [27] & 2001 & USA & 134 & $\begin{array}{c}\text { Chart review } \\
\text { 1949-1999 }\end{array}$ & $\begin{array}{l}\text { Extent of resection or completeness of resection did not } \\
\text { affect survival. }(P>.4) \text {. Postoperative radiotherapy } \\
\text { improved median survival ( } 5 \text { versus } 3 \text { months) but was not } \\
\text { significant }(P<.08) \text {. }\end{array}$ \\
\hline Besic et al. [37] & 2001 & Slovenia & 162 & $\begin{array}{c}\text { Chart review } \\
\text { 1972-1998 }\end{array}$ & $\begin{array}{l}82 \text { patients with distant metastasis at presentation were } \\
\text { excluded. Patients were divided into primary surgery } \\
(n=26) \text { or primary chemotherapy and/or radiation therapy. } \\
\text { One-year survival was similar in both groups }(P=.17) \text {. }\end{array}$ \\
\hline Sugino et al. [38] & 2002 & Japan & 40 & $\begin{array}{c}\text { Chart review } \\
\text { 1989-1999 }\end{array}$ & $\begin{array}{l}\text { The one-year survival rate for surgery was } 60 \% \text {. The survival } \\
\text { rate without surgery was } 21 \% \text {. Surgery and chemotherapy } \\
\text { were both used in some patients. One-year survival rates for } \\
\text { patients with small focus of anaplastic thyroid cancer with } \\
\text { well-differentiated thyroid cancer were } 73 \% \text {. }\end{array}$ \\
\hline
\end{tabular}


TABle 1: Continued.

\begin{tabular}{|c|c|c|c|c|c|}
\hline Authors & Year & Site & $\begin{array}{l}\text { No. of } \\
\text { pts }\end{array}$ & Study details & Results \\
\hline Heron et al. [39] & 2002 & USA & 32 & $\begin{array}{l}\text { Chart review } \\
1952-1999\end{array}$ & $\begin{array}{l}\text { Patients were divided into two groups. Group } 1 \text { patients } \\
\text { between } 1952-80(n=9) \text { and Group } 2 \text { between } 1981-1999 \\
(n=23) \text {. Group } 1 \text { patients received once daily radiation and } \\
\text { Group } 2 \text { patients twice-daily radiation with chemotherapy of } \\
\text { doxorubicin, pacitaxel, vincristine, or cisplatin There was a } \\
\text { combination of therapies in both groups, with the above } \\
\text { generalizations. 2-year survival was } 44 \% \text { in group } 1 \text { and } 52 \% \\
\text { in group 2. Progression-free survival was } 53 \% \text { group } 1 \text { and } \\
38 \% \text { group } 2 \text {. The authors concluded that hyperfractionated } \\
\text { radiation with chemotherapy is associated with better } \\
\text { survival but not progression-free survival. }\end{array}$ \\
\hline Nilsson et al. [18] & 1998 & Sweden & 81 & $\begin{array}{l}\text { Chart review } \\
1971-1997\end{array}$ & $\begin{array}{l}\text { Eight patients ( } 10 \%) \text { survived more than } 2 \text { years and were } \\
\text { treated with combinations of chemotherapy, radiotherapy, } \\
\text { and surgery. }\end{array}$ \\
\hline Tennevall et al. [40] & 1994 & Sweden & 33 & $\begin{array}{c}\text { Chart review } \\
1984-1992\end{array}$ & $\begin{array}{l}\text { Combination of hyperfractionated radiotherapy, } \\
\text { doxorubicin, and debulking surgery. Preoperative radiation } \\
\text { up to } 30 \mathrm{~Gy} \text { and post operative radiation up to } 46 \mathrm{~Gy} .20 \mathrm{mg} \\
\text { doxorubicin per week. } 48 \% \text { had no local recurrence and, } \\
24 \% \text { died due to local failure. In } 4 \text { patients survival exceeded } \\
2 \text { yrs. Local control better with accelerated radiation therapy. }\end{array}$ \\
\hline Venkatesh et al. [24] & 1990 & USA & 121 & Chart review & $\begin{array}{l}\text { Median survival was } 7.2 \pm 10 \text { months. } 35 \% \text { patients had } \\
\text { well-differentiated thyroid cancer as well. }\end{array}$ \\
\hline Junor et al. [10] & 1992 & UK & 91 & $\begin{array}{l}\text { Chart review } \\
1961-1986\end{array}$ & $\begin{array}{l}\text { Surgery and radiation were used. Total or partial } \\
\text { thyroidectomy increased survival. } 80 \% \text { responded to } \\
\text { radiation therapy. }\end{array}$ \\
\hline Levendag et al. [41] & 1993 & Holland & 51 & $\begin{array}{c}\text { Chart review } \\
1970-1986 \\
\end{array}$ & $\begin{array}{l}\text { Local control achieved a median survival of } 7.5 \text { months and } \\
\text { local residual disease } 1.6 \text { months. }\end{array}$ \\
\hline Kim and Leeper [12] & 1987 & USA & 41 & $\begin{array}{l}\text { Chart review } \\
1979-1986\end{array}$ & $\begin{array}{l}\text { Only reporting Group } 2 \text { with anaplastic thyroid cancer. } \\
\text { Weekly doxorubicin } 10 \mathrm{mg} / \mathrm{m}^{2} \text { prior to hyperfractionated } \\
\text { radiotherapy with } 160 \mathrm{cGy} \text { twice daily to total } 57-60 \mathrm{cGy} \text { in } \\
40 \text { days. Initial complete remission rate was } 84 \% \text {. Local } \\
\text { tumor control at } 2 \text { years was } 68 \% \text { with combined therapy. } \\
\text { Median survival was } 1 \text { year. }\end{array}$ \\
\hline
\end{tabular}

as independent predictors of lower cause-specific mortality [52]. In other series, female sex, tumor size less than 6 centimeters, age, and the extent of disease were the most favorable prognostic markers [23, 53]. Among Koreans less than 60 years of age, tumor size less than $7 \mathrm{~cm}$, and lesser disease burden were independent predictors of lower mortality [54]. A recent study from France based on 26 patients with ATC, univariate analysis showed that age above 75 , capsular invasion, lymph nodes metastasis, tumor residue after surgery, and lack of multimodal treatment (particularly radiotherapy in patients without tumor residue) are poor prognosistic factors. Multivariate analysis in the same cohort showed age above 75, followed by node invasion, capsular invasion, and female sex to be poor prognosticators [55]. In a study by Venkatesh and colleagues, patients with localized disease had a median survival of 8 months in comparison to 3 months for patients with metastatic disease [24]. A prognostic index was developed by Sugitani and colleagues from a review of their series of 47 patients over 33 years [56]. Their index was based on a combination of four risk factors: (1) presence of acute symptoms, (2) tumor size greater than 5 centimeters, (3) distant metastasis, and (4) white cell count $\geq$
$10,000 / \mu \mathrm{L}[56]$. Patients with a prognostic index less than or equal to one had a $62 \%$ survival rate at 6 months, whereas all patients with prognostic index of three and four died within six and three months, respectively.

\section{General Therapeutic Approach}

Patients with ATC even in the absence of metastatic disease are considered to have systemic disease at the time of diagnosis. All ATCs are considered stage IV by the International Union Against Cancer (UICC) - TNM staging and American Joint Commission on Cancer (AJCC) system. Multimodality treatment consisting of surgery when feasible combined with radiation and chemotherapy is generally recommended. The surgery must not compromise the functional anatomy of the cervical structures. The most common cause of death is invasion of vital local structures in the neck. Consequently, achieving good local control with surgery and or radiation confers short term palliative and survival benefit. Radiotherapy alone and in combination with surgery has been shown to achieve good local control in many 
studies. There is no consensus on the sequence of radiation and surgery. A summary of retrospective and prospective studies with the most important results are presented in Tables 1 and 2, respectively.

\section{Radiation}

Radiation does not alter the course of ATC in most patients. On the other hand, when combined with surgery and chemotherapy, it can prolong the short-term survival in select and subset of patients. Intensity-modulated radiation therapy (IMRT) based on computerized treatment planning and delivery is able to generate a dose distribution that delivers radiation accurately with sparing of the surrounding normal tissue [57, 58]. Higher doses of radiation can be given over a shorter time with less toxicity by employing hyperfractionation techniques $[59,60]$. Toxicity can be a limiting factor with radiation. Kim and Leeper reported complications particularly, pharyngoesophagitis and tracheitis in their series [12]. Wong and coworkers also noted skin changes, esophageal toxicity, and radiation myelopathy [59]. Daily doses of greater than 3 Gy should be cautiously used as it can increase the incidence of myelopathy [59].

A report from MD Anderson Cancer Center compared outcomes for ATC patients treated with conformal 3dimensional radiotherapy (3DRT) or IMRT. Of the 53 consecutive patients were analyzed, 31 patients were irradiated with curative intent with a median radiation dose of 55 Gray (Gy; range, 4-70 Gy). Thirteen patients received IMRT to a median 60 Gy (range, 39.9-69.0 Gy). The majority of patients received chemotherapy with radiation The Kaplan-Meier estimate of overall survival (OS) at 1 year for definitively irradiated patients was $29 \%$. Five patients without distant metastases had no evidence of disease at last followup. Use of IMRT versus 3DRT did not influence toxicity [71]. Hyperfractionated radiation regimens delivering a total of around 46 Gy have been most effective both with and without doxorubicin [12, 40, 72]. Wong and coworkers also noted skin changes, esophageal toxicity, and radiation myelopathy [59].

\section{Chemotherapy}

It has been found that in vitro, anaplastic cell lines express less multiple drug resistance (mdrl) mRNA and P-glycoprotein while expressing more multidrug resistance-associated protein (MRP) [73, 74]. This could explain the almost uniformly poor outcomes with chemotherapy. Doxorubicin is the most common agent used. A literature review by Ahuja showed a response rate around $22 \%$ for doxorubicin [75]. Swaak-Kragten and others did a retrospective analysis of seventy-five ATC-patients treated between 1972 and 2003 in the Netherlands. Thirty-six patients underwent up-front surgery of which with $53 \%$ had a R0(negative microscopic resection margin)/R1(positive microscopic resection margin) resection. Prior to 1988, adjuvant treatment consisted of conventional radiotherapy (RT) and/or chemotherapy (CT). After 1988, 30 eligible patients were enrolled in a protocol consisting of locoregional radiotherapy in 46 fractions of $1.1 \mathrm{~Gy}$, given twice daily, followed by prophylactic irradiation of the lungs (PLI) in 5 daily fractions of $1.5 \mathrm{~Gy}$. During radiation, low-dose doxorubicin $\left(15 \mathrm{mg} / \mathrm{m}^{2}\right)$ was administered weekly followed by adjuvant doxorubicin $\left(50 \mathrm{mg} / \mathrm{m}^{2}\right) 3$-weekly up to a cumulative dose of $550 \mathrm{mg} / \mathrm{m}^{2}$. Twenty-five ineligible patients were treated conventionally. The overall median survival was 3 months, 1-year OS $9 \%$. Locoregional control was significantly higher in patients who had undergone R0/R1 resection or chemoradiation, with best results for patients who underwent both (complete remission in $89 \%$ ). However, the survival benefit of patients who reached CR remained borderline (median OS 7 months, 1 -year OS 32\%). The three patients who survived for more than 5 years had undergone R0/R1 surgical resection and chemoradiation. Acute toxicity in the protocol group was significantly higher than that in the nonprotocol group, with $46 \%$ versus $11 \%$ grade 3 pharyngeal and/or esophageal toxicity [30].

In a study from Serbia, between 1997 and 2007, 16 inoperable patients were treated with radiotherapy at $60 \mathrm{~Gy}$ followed by doxorubicin $60 \mathrm{mg} / \mathrm{m}^{2}$ and cisplatin $40 \mathrm{mg} / \mathrm{m}^{2}$ every 3 weeks. The overall response rate (ORR) was $25 \%$ ( $95 \%$ CI: 7-55). No toxic deaths occurred or grade 4 adverse events were reported after radiotherapy. Grade 4 toxicity was seen in 3 patients after chemotherapy. Mean patient OS was 12.33 months (95\% CI: 9.09-15.56) and median OS 11.0 months (95\% CI: 8.56-13.44) [31]. Shimaoka and colleagues reported three complete and three partial responders out of 19 patients treated with doxorubicin and cisplatin [76]. Valproic acid, a histone deacetylase inhibitor, enhanced the effect of doxorubicin on anaplastic thyroid cancer cell lines in a preclinical study [77].

Paclitaxel was found to have a response rate of 53\% (95\% confidence interval: $29-76 \%$ ) with one complete response and nine partial responses in 19 evaluable patients in a study conducted by Ain and colleagues [69]. A nonconventional response rate definition was utilized in this study. A recent study done in Japan compared overall survival after induction chemotherapy by weekly paclitaxel administration for patients with stage IVB (nine patients) and IVC (four patients) disease with that of ATC patients with stage IVB $(n=50)$ and IVC $(n=13)$ treated without paclitaxel. Complete response was seen in one, and two demonstrated partial response in the stage IVB group and one patient showed PR in stage IVC. After paclitaxel, curative surgery and adjuvant therapy were performed for four patients with stage IVB. All four patients were reported to be alive and diseasefree 32 months after treatment. All four patients with stage IVC died of carcinoma within 8 months. Overall survival of stage IVB patients with induction chemotherapy was better $(P=.0213)$ than that without the chemotherapy and also better $(P=.0467)$ than those with chemotherapy other than paclitaxel. However, induction chemotherapy did not improve the overall survival of stage IVC patients $(P=.2002)$ [78]. Docetaxel was administered intravenously at a dose of $60 \mathrm{mg} / \mathrm{m}^{2}$ over the course of $1 \mathrm{~h}$ every 3 weeks in seven patients with ATC who had received no prior chemotherapy in recent single center study in Japan. One patient had complete response, two patients had stable disease, and four 
TABle 2: Prospective studies.

\begin{tabular}{|c|c|c|c|c|}
\hline Author & Year & Site & $\begin{array}{c}\text { No. of } \\
\text { pts }\end{array}$ & Study details \\
\hline $\begin{array}{l}\text { Sosa } \\
\text { et al. [61] }\end{array}$ & 2010 & International & 80 & $\begin{array}{l}55 \text { pts were randomized to } \\
\text { paclitaxel/carboplatin and fosbretabulin, } \\
\text { and } 25 \text { patients were randomized to receive } \\
\text { paclitaxel and carboplatin only. Pts were } \\
\text { followed until they died. }\end{array}$ \\
\hline $\begin{array}{l}\text { Troch } \\
\text { et al. [62] }\end{array}$ & 2010 & Austria & 6 & $\begin{array}{l}\text { Standard external beam radiation of } 60 \mathrm{gy} \\
\text { was combined along with docetaxel at } \\
100 \mathrm{mg} \text { fixed dose every } 3 \text { wks for a total of } \\
\text { six cycles starting within the first week of } \\
\text { radiation. }\end{array}$ \\
\hline
\end{tabular}

\begin{tabular}{|c|c|c|c|c|}
\hline $\begin{array}{l}\text { Mooney } \\
\text { et al. [63] }\end{array}$ & 2009 & USA & 26 & $\begin{array}{l}26 \text { patients with biopsy-proven ATC } \\
\text { received fosbretabulin at } 45 \mathrm{mg} / \mathrm{m}^{2} \text {. }\end{array}$ \\
\hline
\end{tabular}

Fosbretabulin was well tolerated with carboplatin and paclitaxel. Improved overall survival (OS) in ATC from 4.1 months to 5.1 months. OS was longer in younger patients $<60$ yrs increasing from medial of 3.1 months to 10.9 months (HR: $0.38,95 \% \mathrm{CI}$ : $0.16,0.88, P=.0222)$.

One patient had only completed radiation at the time of the report. Four patients achieved complete remission, and two achieved partial response. After a median followup of 21.5 months (range, 2-40 months), five patients were alive.

There was no objective response. Median survival was 4.7 months with $34 \%$ and $23 \%$ alive at 6 and 12 months, respectively. Median duration of stable disease in seven patients was 12.3 months (range, 4.4-37.9 months). Lower baseline sICAM-1 levels correlated with better event-free survival. Fosbretabulin was well tolerated with grade 3 toxicity in $34 \%$ and grade 4 in $4 \%$ of patients.

2 of the 15 evaluable patients (13\%) had

Patients with biopsy-proven ATC who had Nagaiah et al. [64] 2009 USA 16 progressed on cytotoxic chemotherapy with or without radiation were treated with sorafenib $400 \mathrm{mg}$ BID on a 28 day cycle. partial response, and 4 patients (27\%) had stable disease. Median time in study was 2 months. Median duration of $\mathrm{PD} / \mathrm{SD}$ was 5.1 months, and median duration of survival was 3.5 months.
Patients were divided into 3 groups. Group A: 19 patients radiotherapy, total thyroidectomy, and chemotherapy. Cisplatin once a week and by radiation at 36 Gy in 18 fractions over 3 weeks, followed by total thyroidectomy and by further chemotherapy with doxorubicin and bleomycin.

Koussis et al. [65] 2006 Italy 56 Additionally, five patients received weekly docetaxel. Group B: consisted of 19 patients with distant metastasis at diagnosis who received chemotherapy (Platinum-based combination). Group C: consisted of 18 elderly patients in poor general condition; 6 received local radiation, while 12 did not receive any treatment.

Hyperfractionated radiotherapy $1.6 \mathrm{~Gy} \times 2$ to a total target dose of 46 Gy given

Wallin et al. [66] 2004 Sweden preoperatively, $20 \mathrm{mg}$ doxorubicin was administered intravenously once weekly and surgery was carried out 2-3 weeks after the radiotherapy.
Five complete responses were seen in patients from Group A. Four patients had long-term survival $(14,15,24$, and 41 months) with a disease-free survival interval of $6,8,11$, and 32 months. Median survival rates for Groups $\mathrm{A}, \mathrm{B}$, and $\mathrm{C}$ was $12,5.7$, and 4 months, respectively.

17 of these 22 patients were operated. Partial regression in 7 others; the one patient whose tumor failed to respond was treated only once daily. Two patients died of spinal cord necrosis and a third of pneumonitis due to the unexpected increase in radiation toxicity caused by the concurrent administration of doxorubicin. None of these 17 patients got a local recurrence. No survival data.

Complete local response was seen in 19 $\begin{array}{llll}\begin{array}{l}\text { De Crevoisier } \\ \text { et al. [67] }\end{array} & 2004 \quad \text { France } & 30 & \begin{array}{l}\text { Hyperfractionated accelerated radiotherapy } \\ \text { and total of } 6 \text { cycles of doxorubicin/cisplatin }\end{array}\end{array}$ patients. Overall survival at 3 years was $27 \%$ and median survival was 10 months. Death was related to local progression in 5\% of patients. 
TABle 2: Continued.

\begin{tabular}{|c|c|c|c|c|c|}
\hline Author & Year & Site & $\begin{array}{c}\text { No. of } \\
\text { pts }\end{array}$ & Study details & Results \\
\hline
\end{tabular}

28 patients with ATC without distant metastases received radiotherapy to the primary tumor and bilateral neck in $1.6 \mathrm{~Gy}$ fractions twice daily and 3 days per week, with concurrent doxorubicin $10 \mathrm{mg} / \mathrm{m}^{2}$ Mitchell et al. [68] 2002 USA 28 weekly. Three histological subsets: anaplastic carcinoma with giant and/or spindle cell features $(n=12)$; anaplastic carcinoma arising from papillary or follicular carcinoma $(n=8)$; and undifferentiated $(n=8)$.

Patients received 96-hour continuous infusion of paclitaxel every 3 weeks for 1 to Ain
et al. [69] $2000 \quad$ USA 20 6 cycles; the first 7 patients received $120 \mathrm{mg} / \mathrm{m}^{2}$ per 96 hours, and the rest received $140 \mathrm{mg} / \mathrm{m}^{2}$ per 96 hours.
The 3-year actuarial local control, metastasis-free survival, and overall survival rates were $47 \%, 8 \%$, and $14 \%$, respectively. Followup among the five currently living patients is $82,27,4,3$, and 1 months, respectively. Site of first failure was distant in 13 patients and local in 7 patients.

Of the 19 evaluable patients, there was a $53 \%$ total response rate $(95 \%$ confidence interval; 29-76\%) including 1 complete response and 9 partial responses (including one off protocol). Nonconventional response criteria.

\begin{tabular}{|c|c|c|c|c|c|}
\hline $\begin{array}{l}\text { Busnardo } \\
\text { et al. [70] }\end{array}$ & 2000 & Italy & 39 & $\begin{array}{l}\text { A total of } 16 \text { patients (Group 1) were treated } \\
\text { with total thyroidectomy, radiation therapy, } \\
\text { and chemotherapy in various orders. Nine } \\
\text { patients with distant metastases at diagnosis } \\
\text { (Group 2) received chemotherapy; one } \\
\text { patient had disappearance of lung } \\
\text { metastases and was then treated by total } \\
\text { thyroidectomy and further chemotherapy. } \\
\text { Group } 3 \text { consisted of } 14 \text { elderly patients in } \\
\text { poor general conditions; } 4 \text { of these received } \\
\text { local radiation therapy, while the remaining } \\
\text { did not receive any treatment. }\end{array}$ & $\begin{array}{l}\text { Median survival rate was } 11 \text { month for } \\
\text { Group } 1 \text {. It was } 5.7 \text { months for Group 2, and } \\
4 \text { months for Group } 3 \text {. Multimodality } \\
\text { treatment was associated with increased } \\
\text { survival. Nine out of } 16 \text { patients, who } \\
\text { underwent surgery and complementary } \\
\text { treatment, had no local progression. }\end{array}$ \\
\hline $\begin{array}{l}\text { Mitchel } \\
\text { et al. [16] }\end{array}$ & 1999 & UK & 17 & $\begin{array}{l}\text { Twice-daily radiation for } 5 \text { days a week to a } \\
\text { total dose of } 60.8 \text { Gy in } 32 \text { fractions over } \\
20-24 \text { days was given in two or three phases. }\end{array}$ & $\begin{array}{l}\text { Three patients with ATC demonstrated a } \\
\text { complete clinical response, and } 7 \text { patients } \\
\text { achieved a partial response. Five patients } \\
\text { had stable disease, and } 2 \text { patients died before } \\
\text { radiotherapy was completed. }\end{array}$ \\
\hline $\begin{array}{l}\text { Schlumberger } \\
\text { et al. [19] }\end{array}$ & 1991 & France & 20 & $\begin{array}{l}\text { Chemotherapy and radiation for patients } \\
\text { aging less than } 65 \text { years treated with } \\
\text { doxorubicin and cisplatin; patients older } \\
\text { than } 65 \text { years with mitoxantrone and } \\
\text { radiation at } 17.5 \mathrm{~Gy} \text {. }\end{array}$ & $\begin{array}{l}\text { Three patients survived more than } 20 \\
\text { months; } 5 \text { patients had complete local } \\
\text { tumor response. }\end{array}$ \\
\hline $\begin{array}{l}\text { Tennevall } \\
\text { et al. [60] }\end{array}$ & 1990 & Sweden & 16 & $\begin{array}{l}\text { Hyperfractionated radiotherapy, } \\
\text { doxorubicin, and debulking surgery. The } \\
\text { radiotherapy was preoperatively } \\
\text { administered to a target dose of } 30 \mathrm{~Gy} \text { in } 3 \\
\text { weeks, and postoperatively to an additional } \\
\text { dose of } 16 \text { Gy in } 1.5 \text { weeks. } 20 \mathrm{mg} \\
\text { doxorubicin was used. }\end{array}$ & $\begin{array}{l}\text { Five patients achieved local complete } \\
\text { remission, and } 3 \text { patients were alive } \\
\text { disease-free at } 10,30 \text {, and } 30 \text { months, } \\
\text { respectively, after diagnosis. Only } 6 \text { patients } \\
\text { succumbed to local failure. }\end{array}$ \\
\hline $\begin{array}{l}\text { Kim and } \\
\text { Leeper [12] }\end{array}$ & 1987 & USA & 19 & $\begin{array}{l}\text { Group } 2 \text { patients with anaplastic giant and } \\
\text { spindle cell carcinoma of the thyroid } \\
(n=19) \text { received doxorubicin }\left(10 \mathrm{mg} / \mathrm{m}^{2}\right) \\
\text { before hyperfractionated radiation. } \\
\text { Radiation therapy was carried out with a } \\
\text { fractional dose of } 160 \text { cGy per treatment } \\
\text { twice a day for } 3 \text { days per week to a total } \\
\text { dose of } 5760 \mathrm{cGy} \text { in } 40 \text { days. }\end{array}$ & $\begin{array}{l}\text { Local tumor control rates at } 2 \text { years after } \\
\text { combined therapy were } 77 \% \text { and } 68 \% \text {, } \\
\text { respectively. The median survival time was } 4 \\
\text { years for group } 1 \text { and } 1 \text { year for group } 2 \text {. }\end{array}$ \\
\hline
\end{tabular}


patients had progressive disease. The response rate was $14 \%$, and the disease control rate (complete/partial response plus stable disease) was $43 \%$. The median time to progression was 6 weeks (range, 1-50). The authors report that the toxicity was tolerable [79]. In a small prospective study of 6 patients from Austria, standard external beam radiation of 60 gy was combined along with docetaxel at $100 \mathrm{mg}$ fixed dose every 3 weeks for a total of six cycles starting within the first week of radiation. One patient had only completed radiation at the time of the report. Four patients achieved complete remission and two partial response. After a median followup of 21.5 months (range, 2-40 months), five patients were alive [62]. Paclitaxel when combined with manumycin showed the most response in combination when compared to either of the agents alone in anaplastic thyroid cancer cell lines in nude mouse [80]. In preclinical studies paclitaxel, gemcitabine, and vinorelbine have showed activity against ATC cell lines [81].

Chemotherapies with bleomycin, etoposide, cisplatin, and methotrexate have poor response rates with no longterm survival $[9,65]$. Other combinations with vincristine and melphalan have not produced any improvements in the rate of responders $[75,82]$.

\section{Emerging Therapies}

As more data becomes available regarding the molecular pathogenesis of ATC, more targeted therapies are appearing in the clinic. Two of the most promising class of agents are the small-molecule tyrosine-kinase angiogenesis inhibitors and vascular disrupting agents. There are two small-molecule tyrosine-kinase inhibitors in the midst of Phase II clinical trials including imatinib mesylate (Gleevac, Novartis, East Hanover, NJ, USA) and sorafenib (Nexavar, Onyx, San Fransisco, Calif, USA). Imatinib mesylate is an orally available selective c-abl tyrosine-kinase inhibitor. It has been shown effective in vitro in anaplastic thyroid cell lines [93, 94]. Another study did not find it effective [95]. Sorafenib is a novel small-molecule tyrosine-kinase inhibitor which acts on the raf-1 serene/threonine kinase. BRAF mutations are thought to be an important event in the evolution of ATC and are a potential therapeutic target for treatment. Sorafenib also blocks the receptor tyrosine kinases to the vascular endothelial growth factor receptor 2 (VEGFR2) and platelet-derived growth factor receptor $\beta$ (PDGFR- $\beta$ ) and thus has antiangiogenesis properties as well. Sorafenib inhibited the growth of rat orthotopic ATC xenografts, and the survival of test animals was improved in recently reported preclinical study [96]. This agent was studied in a clinical trial by Gupta-Abramson and colleagues in patients with advanced thyroid cancer, regardless of histology. Two of the 30 patients studied had anaplastic thyroid cancer. Both patients progressed despite therapy. However, one patient had a $50 \%$ decrease in size of a shoulder nodule at 4 weeks of treatment, before progressing with pericardial nodules at 7 weeks [97]. Sorafenib, at $400 \mathrm{mg}$ bid on a 28 day cycle, was used on 16 patients with ATC, who had failed chemotherapy and/or radiotherapy. Median age was 55 years, two of the 15
(13\%) evaluable patients had partial response, and 4 (23\%) had stable disease. Median time in study was 2 months. Median duration of PD/SD was 5.1 months, and median duration of survival was 3.5 months. This study is ongoing at this time [64].

Axitinib (AG-013736) is an oral, selective inhibitor of VEGFRs 1, 2, and 3, and preclinical studies show that it blocks angiogenesis and tumor blood flow in preclinical models [98]. Cohen and colleagues studied this agent in a clinical trial on patients with advanced thyroid cancer. Two of the 60 patients had ATC. One patient has a partial response, and the other one progressed in spite of treatment [99].

Fosbretabulin is a derived from the African bush willow, Combretum caffrum. It is a novel tubulin-binding, vascular=disrupting agent and should be differentiated from the angiogenesis inhibitors discussed above. It displays potent and selective toxicity towards tumor vasculature and is thought to act by endothelial disruption of established tumor vasculature $[100,101]$. The agent binds avidly to tubulin at the colchicine-binding site to inhibit microtubule assembly and destabilizes the cytoskeleton [102]. Fosbretabulin has also been shown to enhance or act synergistically with radiation and several chemotherapeutic agents [103, 104]. In a Phase II study in 26 patients with ATC, this agent was found to be well tolerated with grade 3 or greater toxicity being observed in $35 \%$ of patients. Median survival was 4.7 months, with $34 \%$ and $23 \%$ alive at 6 and 12 months, respectively. Median duration of stable disease was 12.3 months (range 4.4-37.9). Low-baseline soluble intracellular adhesion molecule-1 (sICAM) appeared to predict better event-free survival [63]. In a Phase $2 / 3$ trial, fosbretabulin, paclitaxel, and carboplatin combination was compared to carboplatin and paclitaxel only in 80 patients with ATC. Interim results have been presented at the European Society of Medical Oncology meeting in Milan, Italy (October 2010). Preliminary results showed that the combination is well tolerated and showed an improvement in overall survival from 4.1 months to 5.1 months, with hazard ration of 0.71. $P$ value could not be calculated, as the study had to be truncated due to poor accrual. One-year survival was almost doubled with fosbretabulin, when compared to chemotherapy alone (23\% versus $9 \%$ ). OS was objectively longer in patients less than 60 years of age, increasing from a median of 3.1 months to 10.9 months ( $\mathrm{HR}$ of $0.38,95 \% \mathrm{CI}$ : $0.16,0.88)[61]$.

In a pilot study, two patients with ATC had intratumor injection of retroviral vector with the human IL-2 gene and the suicide gene thymidine kinase of HSV type 2. Gene therapy resulted in marked increase in $T$-helpertype 1 cytokine profile and induced radiologically proven necrosis in the tumor [105]. Sodium stibogluconate is a trivalent antimonial compound, traditionally used for the treatment of leishmaniasis. It has recently been shown as an inhibitor of selective protein tyrosine phosphatases and could augment immune system activation when combined with interferon alfa-2b [106]. The MMP-activated anthrax lethal toxin (LeTx) was shown to inhibit orthotopic ATC xenograft progression in both toxin-sensitive and toxinresistant ATC cells via reduced endothelial cell recruitment 
TABle 3: Preclinical agents.

\begin{tabular}{|c|c|c|}
\hline Mechanism & Agents & Studies \\
\hline $\begin{array}{l}\text { Loss of p53 or abnormal p53 is expressed in } \\
\text { anaplastic thyroid cancer [83] }\end{array}$ & $\begin{array}{l}\text { Adenovirus with wild } \\
\text { type p53 }\end{array}$ & $\begin{array}{l}\text { Blagosklonny et al. showed that anaplastic thyroid } \\
\text { cancer cell lines infected with the p53 adenovirus } \\
\text { became more sensitive to doxorubicin. }\end{array}$ \\
\hline Unknown [84] & $\begin{array}{l}\text { Bovine seminal } \\
\text { ribonuclease }\end{array}$ & In vivo tumor regression of anaplastic thyroid cancer. \\
\hline $\begin{array}{l}\text { Inhibition of cyclin-dependent kinase activity } \\
\text { [85] }\end{array}$ & $\begin{array}{l}\text { Bone morphogenic } \\
\text { protein }\end{array}$ & Inhibition of 4 of 6 anaplastic thyroid cancer cell lines. \\
\hline EGFR Tyrosine-kinase inhibitor [86] & ZD1839 (gefitinib) & $\begin{array}{l}\text { EGFR is overexpressed in anaplastic thyroid cancer in } \\
\text { vitro/vivo and gefitinib induces apoptosis in vitro and } \\
\text { inhibits subcutaneous mouse models of anaplastic } \\
\text { thyroid cancer. }\end{array}$ \\
\hline EGFR Monoclonal antibody [87] & Cetuximab & $\begin{array}{l}\text { As single agent cetuximab had no activity, but with } \\
\text { irinotecan it inhibited orthotopic anaplastic thyroid } \\
\text { cancer xenografts more than doxorubicin. }\end{array}$ \\
\hline EGRF/VEGF Receptor blocker [88] & AEE788 & $\begin{array}{l}\text { In vitro inhibition and nude-mouse inhibition with } \\
\text { pacitaxel. }\end{array}$ \\
\hline Histone Deacetylase Inhibitors [77, 89-91] & $\begin{array}{l}\text { Valproic acid and } \\
\text { other novel agents }\end{array}$ & $\begin{array}{l}\text { Restored radio iodide uptake and restoration of p } 53 \text { or } \\
\text { pseudo- p53 activity. }\end{array}$ \\
\hline $\begin{array}{l}\text { Inhibition of gelatinase class of matrix } \\
\text { metalloproteinases (MMP) that are activated in } \\
\text { ATC [92] }\end{array}$ & MMP-activated LeTx & $\begin{array}{l}\text { Reduced endothelial cell recruitment and subsequent } \\
\text { tumor vascularization }\end{array}$ \\
\hline
\end{tabular}

and subsequent tumor vascularization [92]. Other agents that have been reported to be effective in vitro studies include replication-competent vaccinia virus (GLV-1h68) [107]. Agents that are in the midst of preclinical evaluation are listed in Table 3.

\section{Summary and Conclusions}

The overall prognosis of ATC continues to be poor, with the 5 -year survival in recent SEER database study to increase the order of $5.6 \%$ to $11.4 \%$ among all regions of the United States [108]. There has not been much improvement in response rates achieved above the $20 \%$ response rate seen with doxorubicin over the years. Further research is needed to evaluate new treatments for this almost uniformly fatal disease.

\section{Abbreviations}

ATC: Anaplastic thyroid cancer

CA4P: Combretastatin A4 phosphate, also known as fosbretabulin.

\section{References}

[1] K. B. Ain, "Anaplastic thyroid carcinoma: a therapeutic challenge," Seminars in Surgical Oncology, vol. 16, no. 1, pp. 64-69, 1999.

[2] J. P. Burke, I. D. Hay, F. Dignan et al., "Long-term trends in thyroid carcinoma: a population-based study in Olmsted County, Minnesota, 1935-1999," Mayo Clinic Proceedings, vol. 80, no. 6, pp. 753-758, 2005.
[3] J. G. Demeter, S. A. De Jong, A. M. Lawrence, and E. Paloyan, "Anaplastic thyroid carcinoma: risk factors and outcome," Surgery, vol. 110, no. 6, pp. 956-963, 1991.

[4] J. M. Goldman, E. N. Goren, M. H. Cohen, B. L. Webber, M. F. Brennan, and J. Robbins, "Anaplastic thyroid carcinoma: long-term survival after radical surgery," Journal of Surgical Oncology, vol. 14, no. 4, pp. 389-394, 1980.

[5] T. Hadar, C. Mor, J. Shvero, R. Levy, and K. Segal, "Anaplastic carcinoma of the thyroid," European Journal of Surgical Oncology, vol. 19, no. 6, pp. 511-516, 1993.

[6] P. I. Haigh, P. H. Ituarte, H. S. Wu et al., "Completely resected anaplastic thyroid carcinoma combined with adjuvant chemotherapy and irradiation is associated with prolonged survival," Cancer, vol. 91, no. 12, pp. 2335-2342, 2001.

[7] S. A. Hundahl, B. Cady, M. P. Cunningham et al., "Initial results from a prospective cohort study of 5583 cases of thyroid carcinoma treated in the united states during 1996. U.S. and German Thyroid Cancer Study Group. An American College of Surgeons Commission on Cancer Patient Care Evaluation study," Cancer, vol. 89, no. 1, pp. 202-217, 2000.

[8] S. A. Hundahl, I. D. Fleming, A. M. Fremgen, and H. R. Menck, "A National Cancer Data Base report on 53,856 cases of thyroid carcinoma treated in the U.S., 1985-1995," Cancer, vol. 83, no. 12, pp. 2638-2648, 1998.

[9] B. Jereb, J. Stjernsward, and T. Lowhagen, "Anaplastic giant cell carcinoma of the thyroid. A study of treatment and prognosis," Cancer, vol. 35, no. 5, pp. 1293-1295, 1975.

[10] E. J. Junor, J. Paul, and N. S. Reed, "Anaplastic thyroid carcinoma: 91 patients treated by surgery and radiotherapy," European Journal of Surgical Oncology, vol. 18, no. 2, pp. 8388, 1992.

[11] E. Kebebew, F. S. Greenspan, O. H. Clark, K. A. Woeber, and A. McMillan, "Anaplastic thyroid carcinoma: treatment outcome and prognostic factors," Cancer, vol. 103, no. 7, pp. 1330-1335, 2005. 
[12] J. H. Kim and R. D. Leeper, "Treatment of locally advanced thyroid carcinoma with combination doxorubicin and radiation therapy," Cancer, vol. 60, no. 10, pp. 2372-2375, 1987.

[13] J. H. Kim and R. D. Leeper, "Combination adriamycin and radiation therapy for locally advanced carcinoma of the thyroid gland," International Journal of Radiation Oncology Biology Physics, vol. 9, no. 4, pp. 565-567, 1983.

[14] J. Kurebayashi, S. Okubo, Y. Yamamoto et al., "Additive antitumor effects of gefitinib and imatinib on anaplastic thyroid cancer cells," Cancer Chemotherapy and Pharmacology, vol. 58, no. 4, pp. 460-470, 2006.

[15] K. Y. Lam, C. Y. Lo, K. W. Chan, and K. Y. Wan, "Insular and anaplastic carcinoma of the thyroid: a 45-year comparative study at a single institution and a review of the significance of p53 and p21," Annals of Surgery, vol. 231, no. 3, pp. 329$338,2000$.

[16] G. Mitchell, R. Huddart, and C. Harmer, "Phase II evaluation of high dose accelerated radiotherapy for anaplastic thyroid carcinoma," Radiotherapy and Oncology, vol. 50, no. 1, pp. 33-38, 1999.

[17] C. J. Nel, J. A. van Heerden, J. R. Goellner et al., "Anaplastic carcinoma of the thyroid: a clinicopathologic study of 82 cases," Mayo Clinic Proceedings, vol. 60, no. 1, pp. 51-58, 1985.

[18] O. Nilsson, J. Lindeberg, J. Zedenius et al., "Anaplastic giant cell carcinoma of the thyroid gland: treatment and survival over a 25-year period," World Journal of Surgery, vol. 22, no. 7, pp. 725-730, 1998.

[19] M. Schlumberger, C. Parmentier, M. J. Delisle, J. E. Couette, J. P. Droz, and D. Sarrazin, "Combination therapy for anaplastic giant cell thyroid carcinoma," Cancer, vol. 67, no. 3, pp. 564-566, 1991.

[20] W. J. Simpson, "Anaplastic thyroid carcinoma: a new approach," Canadian Journal of Surgery, vol. 23, no. 1, pp. 25-27, 1980.

[21] J. R. Spires, M. R. Schwartz, and R. H. Miller, "Anaplastic thyroid carcinoma. Association with differentiated thyroid cancer," Archives of Otolaryngology, vol. 114, no. 1, pp. 40-44, 1988.

[22] E. Tallroth, G. Wallin, G. Lundell, T. Lowhagen, and J. Einhorn, "Multimodality treatment in anaplastic giant cell thyroid carcinoma," Cancer, vol. 60, no. 7, pp. 1428-1431, 1987.

[23] R. K. Tan, R. K. Finley III, D. Driscoll, V. Bakamjian, W. L. Hicks Jr., and D. P. Shedd, "Anaplastic carcinoma of the thyroid: a 24-year experience," Head \& Neck, vol. 17, no. 1, pp. 41-48, 1995.

[24] Y. S. Venkatesh, N. G. Ordonez, P. N. Schultz, R. C. Hickey, H. Goepfert, and N. A. Samaan, "Anaplastic carcinoma of the thyroid. A clinicopathologic study of 121 cases," Cancer, vol. 66, no. 2, pp. 321-330, 1990.

[25] P. E. Voutilainen, M. Multanen, R. K. Haapiainen, A. K. Leppaniemi, and A. H. Sivula, "Anaplastic thyroid carcinoma survival," World Journal of Surgery, vol. 23, no. 9, pp. 975 978, 1999.

[26] C. Are and A. R. Shaha, "Anaplastic thyroid carcinoma: biology, pathogenesis, prognostic factors, and treatment approaches," Annals of Surgical Oncology, vol. 13, no. 4, pp. 453-464, 2006.

[27] B. McIver, I. D. Hay, D. F. Giuffrida et al., "Anaplastic thyroid carcinoma: a 50-year experience at a single institution," Surgery, vol. 130, no. 6, pp. 1028-1034, 2001.
[28] A. Jemal, R. Siegel, E. Ward, T. Murray, J. Xu, and M. J. Thun, "Cancer statistics, 2007," CA: A Cancer Journal for Clinicians, vol. 57, no. 1, pp. 43-66, 2007.

[29] L. Davies and H. G. Welch, "Increasing incidence of thyroid cancer in the United States, 1973-2002," Journal of the American Medical Association, vol. 295, no. 18, pp. 21642167, 2006.

[30] A. T. Swaak-Kragten, J. H. de Wilt, P. I. Schmitz, M. Bontenbal, and P. C. Levendag, "Multimodality treatment for anaplastic thyroid carcinoma-treatment outcome in 75 patients," Radiotherapy and Oncology, vol. 92, no. 1, pp. 100104, 2009.

[31] S. Vrbic, I. Pejcic, M. Vrbic, and S. Filipovic, "Therapy of stage IV B anaplastic thyroid carcinoma: single institution experience," Journal of Balkan Union of Oncology, vol. 14, no. 1, pp. 41-44, 2009.

[32] T. Yau, C. Y. Lo, R. J. Epstein, A. K. Lam, K. Y. Wan, and B. H. Lang, "Treatment outcomes in anaplastic thyroid carcinoma: survival improvement in young patients with localized disease treated by combination of surgery and radiotherapy," Annals of Surgical Oncology, vol. 15, no. 9, pp. 2500-2505, 2008.

[33] S. Lim, N. Lee, M. G. Fury et al., "Doxorubucin and concurrent radiotherapy for anaplastic thyroid cancer: we need to do better," Journal of Clinical Oncology, vol. 25, no. 18S, abstract 735, 2007.

[34] Y. Lee, J. Jung, H. Hwang, and Y. Im, "Multimodal therapeutic approach in anaplastic thyroid cancer," Journal of Clinical Oncology, vol. 24, supplement, article 15533, no. 18S, 2006.

[35] Y. Wang, R. Tsang, S. Asa, B. Dickson, T. Arenovich, and J. Brierley, "Clinical outcome of anaplastic thyroid carcinoma treated with radiotherapy of once- and twice-daily fractionation regimens," Cancer, vol. 107, no. 8, pp. 1786-1792, 2006.

[36] M. J. Veness, G. S. Porter, and G. J. Morgan, "Anaplastic thyroid carcinoma: dismal outcome despite current treatment approach," Australian and New Zealand Journal of Surgery, vol. 74, no. 7, pp. 559-562, 2004.

[37] N. Besic, M. Auersperg, M. Us-Krasovec, R. Golouh, S. Frkovic-Grazio, and A. Vodnik, "Effect of primary treatment on survival in anaplastic thyroid carcinoma," European Journal of Surgical Oncology, vol. 27, no. 3, pp. 260-264, 2001.

[38] K. Sugino, K. Ito, T. Mimura et al., "The important role of operations in the management of anaplastic thyroid carcinoma," Surgery, vol. 131, no. 3, pp. 245-248, 2002.

[39] D. E. Heron, S. Karimpour, and P. W. Grigsby, "Anaplastic thyroid carcinoma: comparison of conventional radiotherapy and hyperfractionation chemoradiotherapy in two groups," American Journal of Clinical Oncology, vol. 25, no. 5, pp. 442-446, 2002.

[40] J. Tennvall, G. Lundell, A. Hallquist, P. Wahlberg, G. Wallin, and S. Tibblin, "Combined doxorubicin, hyperfractionated radiotherapy, and surgery in anaplastic thyroid carcinoma. Report on two protocols. The Swedish Anaplastic Thyroid Cancer Group," Cancer, vol. 74, no. 4, pp. 1348-1354, 1994.

[41] P. C. Levendag, P. M. De Porre, and W. L. van Putten, "Anaplastic carcinoma of the thyroid gland treated by radiation therapy," International Journal of Radiation Oncology Biology Physics, vol. 26, no. 1, pp. 125-128, 1993.

[42] S. Agrawal, R. S. Rao, D. M. Parikh, H. K. Parikh, A. M. Borges, and M. B. Sampat, "Histologic trends in thyroid cancer 1969-1993: a clinico-pathologic analysis of the relative proportion of anaplastic carcinoma of the thyroid," Journal of Surgical Oncology, vol. 63, no. 4, pp. 251-255, 1996. 
[43] P. Lampertico, "Anaplastic (sarcomatoid) carcinoma of the thyroid gland," Seminars in Diagnostic Pathology, vol. 10, no. 2, pp. 159-168, 1993.

[44] P. Trimboli, S. Ulisse, F. M. Graziano et al., "Trend in thyroid carcinoma size, age at diagnosis, and histology in a retrospective study of 500 cases diagnosed over 20 years," Thyroid, vol. 16, no. 11, pp. 1151-1155, 2006.

[45] H. Ezaki, S. Ebihara, Y. Fujimoto et al., "Analysis of thyroid carcinoma based on material registered in Japan during 1977-1986 with special reference to predominance of papillary type," Cancer, vol. 70, no. 4, pp. 808-814, 1992.

[46] W. Kitagawa, K. Shimizu, H. Akasu, and S. Tanaka, "Endocrine surgery. The ninth report: the latest data on and clinical characteristics of the epidemiology of thyroid carcinoma," Journal of Nippon Medical School, vol. 70, no. 1, pp. 57-61, 2003.

[47] P. C. Ratnatunga, S. C. Amarasinghe, and N. V. Ratnatunga, "Changing patterns of thyroid cancer in Sri Lanka. Has the iodination programme helped?" The Ceylon Medical Journal, vol. 48, no. 4, pp. 125-128, 2003.

[48] R. M. Reynolds, J. Weir, D. L. Stockton, D. H. Brewster, T. C. Sandeep, and M. W. Strachan, "Changing trends in incidence and mortality of thyroid cancer in Scotland," Clinical Endocrinology, vol. 62, no. 2, pp. 156-162, 2005.

[49] F. Bakiri, F. K. Djemli, L. A. Mokrane, and F. K. Djidel, "The relative roles of endemic goiter and socioeconomic development status in the prognosis of thyroid carcinoma," Cancer, vol. 82, no. 6, pp. 1146-1153, 1998.

[50] N. Besic, M. Hocevar, and J. Zgajnar, "Lower incidence of anaplastic carcinoma after higher iodination of salt in slovenia," Thyroid, vol. 20, no. 6, pp. 623-626, 2010.

[51] J. Chen, J. D. Tward, D. C. Shrieve, and Y. J. Hitchcock, "Surgery and radiotherapy improves survival in patients with anaplastic thyroid carcinoma: analysis of the surveillance, epidemiology, and end results 1983-2002," American Journal of Clinical Oncology, vol. 31, no. 5, pp. 460-464, 2008.

[52] F. D. Gilliland, W. C. Hunt, D. M. Morris, and C. R. Key, "Prognostic factors for thyroid carcinoma. A populationbased study of 15,698 cases from the Surveillance, Epidemiology and End Results (SEER) program 1973-1991," Cancer, vol. 79, no. 3, pp. 564-573, 1997.

[53] C. Y. Lo, K. Y. Lam, and K. Y. Wan, "Anaplastic carcinoma of the thyroid," The American Journal of Surgery, vol. 177, no. 4, pp. 337-339, 1999.

[54] T. Y. Kim, K. W. Kim, T. S. Jung et al., "Prognostic factors for korean patients with anaplastic thyroid carcinoma," Head \& Neck, vol. 29, no. 8, pp. 765-772, 2007.

[55] B. Roche, G. Larroumets, C. Dejax et al., "Epidemiology, clinical presentation, treatment and prognosis of a regional series of 26 anaplastic thyroid carcinomas (ATC). Comparison with the literature," Annales d'Endocrinologie, vol. 71, no. 1, pp. $38-45,2010$.

[56] I. Sugitani, N. Kasai, Y. Fujimoto, and A. Yanagisawa, "Prognostic factors and therapeutic strategy for anaplastic carcinoma of the thyroid," World Journal of Surgery, vol. 25, no. 5, pp. 617-622, 2001.

[57] N. Lee, D. R. Puri, A. I. Blanco, and K. S. Chao, "Intensitymodulated radiation therapy in head and neck cancers: an update," Head \& Neck, vol. 29, no. 4, pp. 387-400, 2007.

[58] B. D. Rosenbluth, V. Serrano, L. Happersett et al., "Intensity-modulated radiation therapy for the treatment of nonanaplastic thyroid cancer," International Journal of Radiation Oncology Biology Physics, vol. 63, no. 5, pp. 14191426, 2005.
[59] C. S. Wong, J. Van Dyk, and W. J. Simpson, "Myelopathy following hyperfractionated accelerated radiotherapy for anaplastic thyroid carcinoma," Radiotherapy and Oncology, vol. 20, no. 1, pp. 3-9, 1991.

[60] J. Tennvall, E. Tallroth, A. el Hassan et al., "Anaplastic thyroid carcinoma. Doxorubicin, hyperfractionated radiotherapy and surgery," Acta Oncologica, vol. 29, no. 8, pp. 1025-1028, 1990.

[61] J. A. Sosa, R. Elisei, B. Jarzab et al., "Randomized phase $2 / 3$ trial of a tunor vascular disrupting agent, fosbertubulin (CA4P), with carboplatin $(\mathrm{C})$, and paclitaxel(P) in anaplastic thyroid cancer(ATC): interim safety and efficacy results of the FACT trial," Milan, Italy, 2010.

[62] M. Troch, O. Koperek, C. Scheuba et al., "High efficacy of concomitant treatment of undifferentiated (anaplastic) thyroid cancer with radiation and docetaxel," Journal of Clinical Endocrinology \& Metabolism, vol. 95, no. 9, pp. E54E57, 2010.

[63] C. J. Mooney, G. Nagaiah, P. Fu et al., "A phase II trial of fosbretabulin in advanced anaplastic thyroid carcinoma and correlation of baseline serum-soluble intracellular adhesion molecule-1 with outcome," Thyroid, vol. 19, no. 3, pp. 233240, 2009.

[64] G. Nagaiah, P. Fu, J. K. Wasman et al., "Phase II trial of sorafenib (bay 43-9006) in patients with advanced anaplastic carcinoma of the thyroid (ATC)," Journal of Clinical Oncology, vol. 27, no. 15S, supplement, 2009, abstract 6058.

[65] H. Koussis, A. Scola, S. Tonello et al., "Multimodality therapeutic approach in anaplastic thyroid cancer (ATC): study of 56 patients," Journal of Clinical Oncology, vol. 24, no. 18S, supplement, 2006, ASCO Annual Meeting Proceedings Part I. Vol. 24.

[66] G. Wallin, G. Lundell, and J. Tennvall, "Anaplastic giant cell thyroid carcinoma," Scandinavian Journal of Surgery, vol. 93, no. 4, pp. 272-277, 2004.

[67] R. De Crevoisier, E. Baudin, A. Bachelot et al., "Combined treatment of anaplastic thyroid carcinoma with surgery, chemotherapy, and hyperfractionated accelerated external radiotherapy," International Journal of Radiation Oncology Biology Physics, vol. 60, no. 4, pp. 1137-1143, 2004.

[68] F. W. Mitchel, L. W. Suzanne, G. H. Andrew et al., "Hyperfractionated radiation therapy and adriamycin for anaplastic thyroid cancer," Proceedings American Society of Clinical Oncology, vol. 21, abstract 931, 2002.

[69] K. B. Ain, M. J. Egorin, and P. A. DeSimone, "Treatment of anaplastic thyroid carcinoma with paclitaxel: phase 2 trial using ninety-six-hour infusion. Collaborative Anaplastic Thyroid Cancer Health Intervention Trials (CATCHIT) Group," Thyroid, vol. 10, no. 7, pp. 587-594, 2000.

[70] B. Busnardo, O. Daniele, M. R. Pelizzo et al., "A multimodality therapeutic approach in anaplastic thyroid carcinoma: study on 39 patients," Journal of Endocrinological Investigation, vol. 23, no. 11, pp. 755-761, 2000.

[71] A. Bhatia, A. Rao, K. K. Ang et al., "Anaplastic thyroid cancer: clinical outcomes with conformal radiotherapy," Head \& Neck, vol. 32, no. 7, pp. 829-836, 2010.

[72] J. Tennvall, G. Lundell, P. Wahlberg et al., "Anaplastic thyroid carcinoma: three protocols combining doxorubicin, hyperfractionated radiotherapy and surgery," British Journal of Cancer, vol. 86, no. 12, pp. 1848-1853, 2002.

[73] M. Lehnert, "Clinical multidrug resistance in cancer: a multifactorial problem," European Journal of Cancer, vol. 32, no. 6, pp. 912-920, 1996. 
[74] S. Satake, I. Sugawara, M. Watanabe, and H. Takami, "Lack of a point mutation of human DNA topoisomerase II in multidrug-resistant anaplastic thyroid carcinoma cell lines," Cancer Letters, vol. 116, no. 1, pp. 33-39, 1997.

[75] S. Ahuja and H. Ernst, "Chemotherapy of thyroid carcinoma," Journal of Endocrinological Investigation, vol. 10, no. 3, pp. 303-310, 1987.

[76] K. Shimaoka, D. A. Schoenfeld, and W. D. DeWys, "A randomized trial of doxorubicin versus doxorubicin plus cisplatin in patients with advanced thyroid carcinoma," Cancer, vol. 56, no. 9, pp. 2155-2160, 1985.

[77] M. G. Catalano, N. Fortunati, M. Pugliese et al., "Valproic acid, a histone deacetylase inhibitor, enhances sensitivity to doxorubicin in anaplastic thyroid cancer cells," Journal of Endocrinology, vol. 191, no. 2, pp. 465-472, 2006.

[78] T. Higashiyama, Y. Ito, M. Hirokawa et al., "Induction chemotherapy with weekly paclitaxel administration for anaplastic thyroid carcinoma," Thyroid, vol. 20, no. 1, pp. 7$14,2010$.

[79] K. Kawada, K. Kitagawa, S. Kamei et al., "The feasibility study of docetaxel in patients with anaplastic thyroid cancer," Japanese Journal of Clinical Oncology, vol. 40, no. 6, pp. 596$599,2010$.

[80] S. C. Yeung, G. Xu, J. Pan, M. Christgen, and A. Bamiagis, "Manumycin enhances the cytotoxic effect of paclitaxel on anaplastic thyroid carcinoma cells," Cancer Research, vol. 60, no. 3, pp. 650-656, 2000.

[81] W. Voigt, T. Kegel, M. Weiss, T. Mueller, H. Simon, and H. J. Schmoll, "Potential activity of paclitaxel, vinorelbine and gemcitabine in anaplastic thyroid carcinoma," Journal of Cancer Research and Clinical Oncology, vol. 131, no. 9, pp. 585-590, 2005.

[82] M. Sokal and C. L. Harmer, "Chemotherapy for anaplastic carcinoma of the thyroid," Clinical Oncology, vol. 4, no. 1, pp. 3-10, 1978.

[83] M. V. Blagosklonny, P. Giannakakou, M. Wojtowicz et al., "Effects of p53-expressing adenovirus on the chemosensitivity and differentiation of anaplastic thyroid cancer cells," Journal of Clinical Endocrinology \& Metabolism, vol. 83, no. 7, pp. 2516-2522, 1998.

[84] R. Kotchetkov, J. Cinatl, A. A. Krivtchik et al., "Selective activity of BS-RNase against anaplastic thyroid cancer," Anticancer Research, vol. 21, no. 2A, pp. 1035-1042, 2001.

[85] A. Franzen and N. E. Heldin, "BMP-7-induced cell cycle arrest of anaplastic thyroid carcinoma cells via p21(CIP1) and p27(KIP1)," Biochemical and Biophysical Research Communications, vol. 285, no. 3, pp. 773-781, 2001.

[86] B. A. Schiff, A. B. McMurphy, S. A. Jasser et al., "Epidermal growth factor receptor (EGFR) is overexpressed in anaplastic thyroid cancer, and the EGFR inhibitor gefitinib inhibits the growth of anaplastic thyroid cancer," Clinical Cancer Research, vol. 10, no. 24, pp. 8594-8602, 2004.

[87] S. Kim, C. N. Prichard, M. N. Younes et al., "Cetuximab and irinotecan interact synergistically to inhibit the growth of orthotopic anaplastic thyroid carcinoma xenografts in nude mice," Clinical Cancer Research, vol. 12, no. 2, pp. 600-607, 2006.

[88] S. Kim, B. A. Schiff, O. G. Yigitbasi et al., "Targeted molecular therapy of anaplastic thyroid carcinoma with AEE788," Molecular Cancer Therapeutics, vol. 4, no. 4, pp. 632-640, 2005.

[89] F. Furuya, H. Shimura, H. Suzuki et al., "Histone deacetylase inhibitors restore radioiodide uptake and retention in poorly differentiated and anaplastic thyroid cancer cells by expression of the sodium/iodide symporter thyroperoxidase and thyroglobulin," Endocrinology, vol. 145, no. 6, pp. 28652875, 2004.

[90] R. Imanishi, A. Ohtsuru, M. Iwamatsu et al., "A histone deacetylase inhibitor enhances killing of undifferentiated thyroid carcinoma cells by p53 gene therapy," Journal of Clinical Endocrinology \& Metabolism, vol. 87, no. 10, pp. 4821-4824, 2002.

[91] C. S. Mitsiades, V. Poulaki, C. McMullan et al., "Novel histone deacetylase inhibitors in the treatment of thyroid cancer," Clinical Cancer Research, vol. 11, no. 10, pp. 3958-3965, 2005.

[92] R. W. Alfano, S. H. Leppla, S. Liu et al., "Inhibition of tumor angiogenesis by the matrix metalloproteinaseactivated anthrax lethal toxin in an orthotopic model of anaplastic thyroid carcinoma," Molecular Cancer Therapeutics, vol. 9, no. 1, pp. 190-201, 2010.

[93] A. Podtcheko, A. Ohtsuru, H. Namba et al., "Inhibition of ABL tyrosine kinase potentiates radiation-induced terminal growth arrest in anaplastic thyroid cancer cells," Radiation Research, vol. 165, no. 1, pp. 35-42, 2006.

[94] A. Podtcheko, A. Ohtsuru, S. Tsuda et al., "The selective tyrosine kinase inhibitor, STI571, inhibits growth of anaplastic thyroid cancer cells," Journal of Clinical Endocrinology \& Metabolism, vol. 88, no. 4, pp. 1889-1896, 2003.

[95] J. M. Dziba and K. B. Ain, "Imatinib mesylate (gleevec; STI571) monotherapy is ineffective in suppressing human anaplastic thyroid carcinoma cell growth in vitro," Journal of Clinical Endocrinology \& Metabolism, vol. 89, no. 5, pp. 21272135, 2004.

[96] S. Kim, Y. D. Yazici, G. Calzada et al., "Sorafenib inhibits the angiogenesis and growth of orthotopic anaplastic thyroid carcinoma xenografts in nude mice," Molecular Cancer Therapeutics, vol. 6, no. 6, pp. 1785-1792, 2007.

[97] V. Gupta-Abramson, A. B. Troxel, A. Nellore et al., "Phase II trial of sorafenib in advanced thyroid cancer," Journal of Clinical Oncology, vol. 26, no. 29, pp. 4714-4719, 2008.

[98] T. Inai, M. Mancuso, H. Hashizume et al., "Inhibition of vascular endothelial growth factor (VEGF) signaling in cancer causes loss of endothelial fenestrations, regression of tumor vessels, and appearance of basement membrane ghosts," American Journal of Pathology, vol. 165, no. 1, pp. 35-52, 2004.

[99] E. E. Cohen, L. S. Rosen, E. E. Vokes et al., "Axitinib is an active treatment for all histologic subtypes of advanced thyroid cancer: results from a phase II study," Journal of Clinical Oncology, vol. 26, no. 29, pp. 4708-4713, 2008.

[100] G. G. Dark, S. A. Hill, V. E. Prise, G. M. Tozer, G. R. Pettit, and D. J. Chaplin, "Combretastatin A-4, an agent that displays potent and selective toxicity toward tumor vasculature," Cancer Research, vol. 57, no. 10, pp. 1829-1834, 1997.

[101] L. Vincent, P. Kermani, L. M. Young et al., "Combretastatin A4 phosphate induces rapid regression of tumor neovessels and growth through interference with vascular endothelialcadherin signaling," Journal of Clinical Investigation, vol. 115, no. 11, pp. 2992-3006, 2005.

[102] G. R. Pettit, S. B. Singh, E. Hamel, C. M. Lin, D. S. Alberts, and D. Garcia-Kendall, "Isolation and structure of the strong cell growth and tubulin inhibitor combretastatin A-4," Experientia, vol. 45, no. 2, pp. 209-211, 1989.

[103] K. Grosios, P. M. Loadman, D. J. Swaine, G. R. Pettit, and M. C. Bibby, "Combination chemotherapy with combretastatin A-4 phosphate and 5-fluorouracil in an experimental murine 
colon adenocarcinoma," Anticancer Research, vol. 20, no. 1, pp. 229-233, 2000.

[104] R. Murata, D. W. Siemann, J. Overgaard, and M. R. Horsman, "Interaction between combretastatin A-4 disodium phosphate and radiation in murine tumors," Radiotherapy and Oncology, vol. 60, no. 2, pp. 155-161, 2001.

[105] L. Barzon, M. Pacenti, A. Taccaliti et al., "A pilot study of combined suicide/cytokine gene therapy in two patients with end-stage anaplastic thyroid carcinoma," Journal of Clinical Endocrinology \& Metabolism, vol. 90, no. 5, pp. 2831-2834, 2005.

[106] M. K. Pathak and T. Yi, "Sodium stibogluconate is a potent inhibitor of protein tyrosine phosphatases and augments cytokine responses in hemopoietic cell lines," Journal of Immunology, vol. 167, no. 6, pp. 3391-3397, 2001.

[107] S. F. Lin, Z. Yu, C. Riedl et al., "Treatment of anaplastic thyroid carcinoma in vitro with a mutant vaccinia virus," Surgery, vol. 142, no. 6, pp. 976-983, 2007.

[108] G. P. Yu, J. C. Li, D. Branovan, S. McCormick, and S. P. Schantz, "Thyroid cancer incidence and survival in the national cancer institute surveillance, epidemiology, and end results race/ethnicity groups," Thyroid, vol. 20, no. 5, pp. 465-473, 2010. 


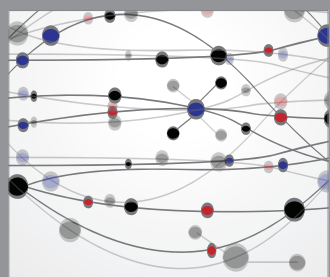

The Scientific World Journal
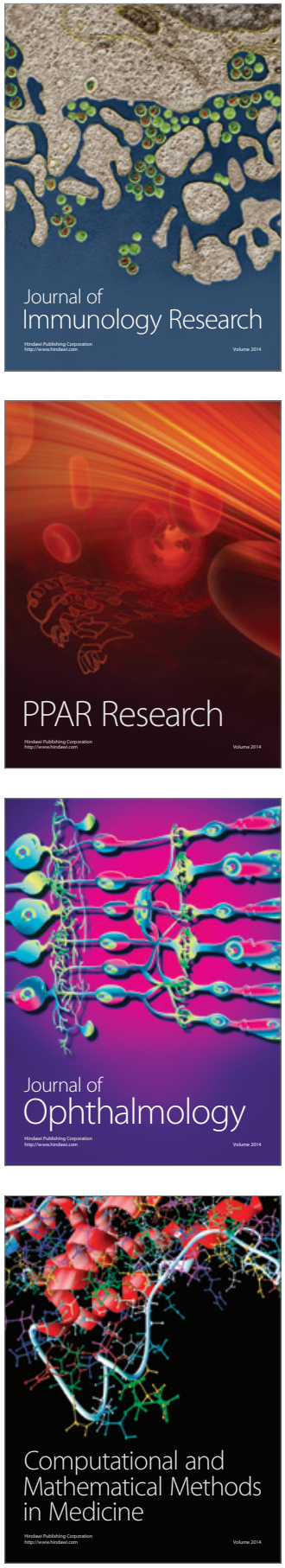

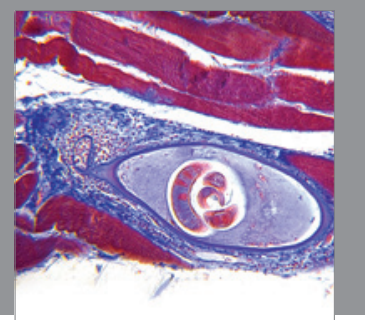

Gastroenterology

Research and Practice
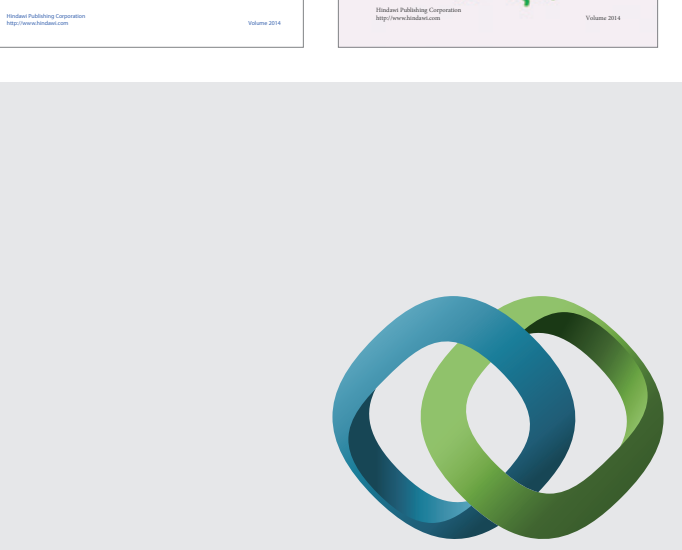

\section{Hindawi}

Submit your manuscripts at

http://www.hindawi.com
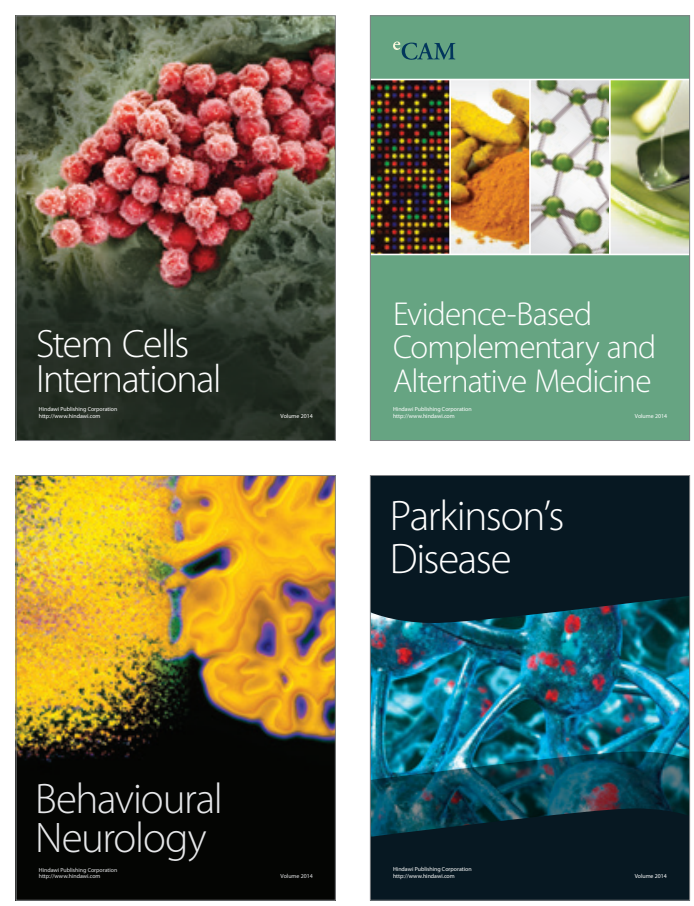

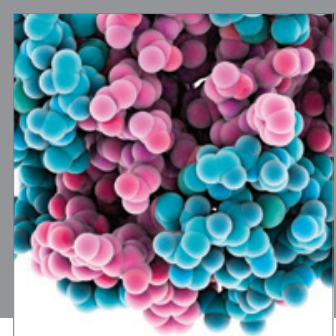

Journal of
Diabetes Research

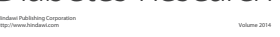

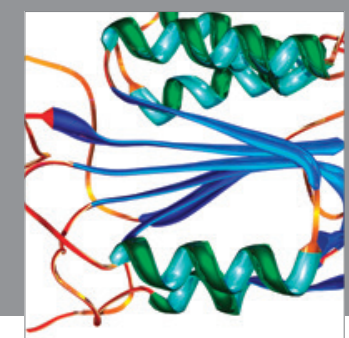

Disease Markers
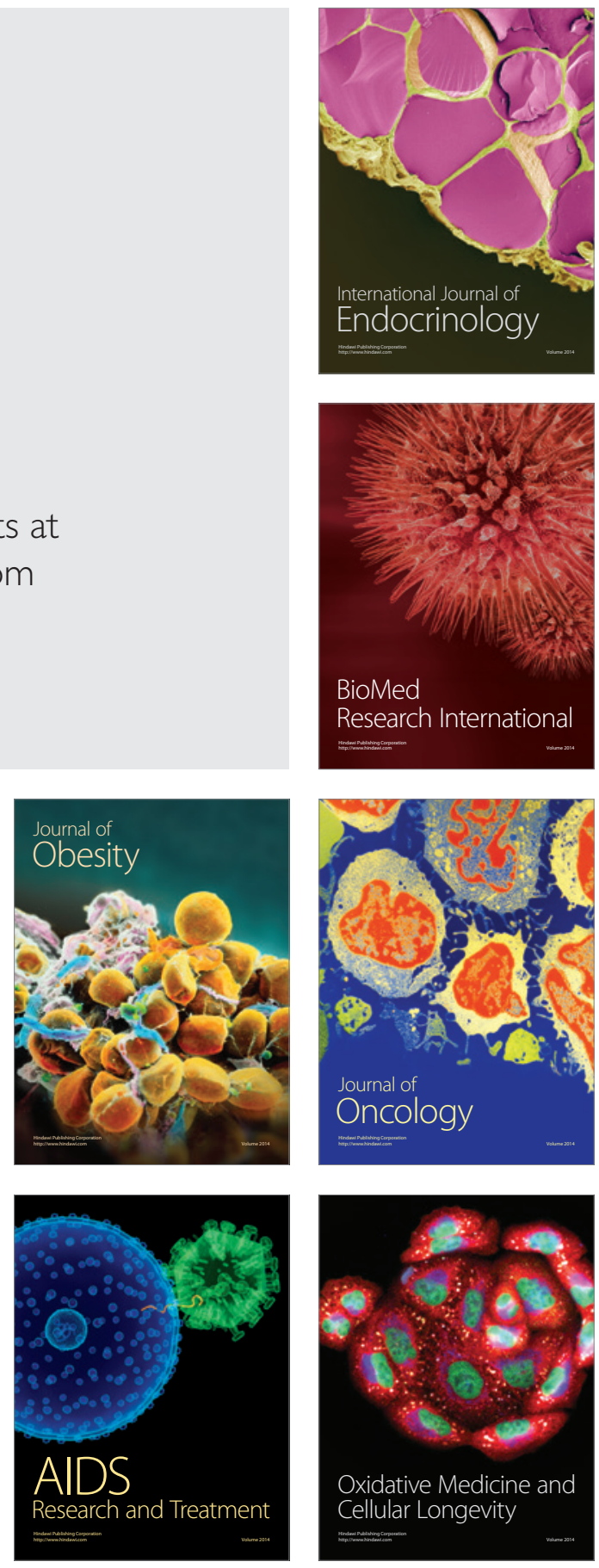